\title{
Influence of the nature of carbohydrate intake on the absorption chronology of reducing sugars and volatile fatty acids in the pig
}

\author{
A Rérat \\ Département de nutrition, alimentation, sécurité alimentaire, Centre de rècherche de Jouy, Inra, \\ 78352 Jouy-en-Josas cedex, France
}

(Received 23 September 1994; accepted 2 November 1995)

\begin{abstract}
Summary - The results of three successive experiments were compared in order to analyse the chronology of absorbed energy amounts resulting from enzymatic or microbial digestion, respectively. These experiments were undertaken in the pig to study the absorption kinetics of reducing sugars and amino-nitrogen formed during enzymatic digestion and of volatile fatty acids (VFA) formed through the action of the digestive flora. The animals were given well-balanced semi-synthetic diets containing poorly digestible or indigestible carbohydrates. These diets contained the following ingredients: (Experiment A) purified cellulose at two levels of incorporation ( $\mathrm{LC}$ diet 6\%, $\mathrm{HC}$ diet $16 \%$ ); (Experiment $B$ ) alfalfa meal $(22 \%)$ supplying $6 \%$ crude fibre (HA diet) versus lactose $(22 \%)$ with an addition of $6 \%$ purified cellulose (HL diet); (Experiment C) sorbitol in the form of maltitol $(53 \%$ ) with an addition of $6 \%$ purified cellulose (SHyd diet) versus maltose under the same conditions (53\%, SNat diet). Each diet was fed to five pigs fitted with catheters placed in the portal vein and carotid artery and with a flow probe around the portal vein, which made it possible to study the nutrient absorption after one meal $(800 \mathrm{~g})$. Under our experimental conditions (intake: $2200-2300 \mathrm{kcal}$, except HC $1930 \mathrm{kcal}$ ) the higher level of crude fibre or the presence of osides in the diet which are poorly digestible in the small intestine (lactose, maltitol), depressed the absorption of reducing sugars (RS) (amount absorbed within $12 \mathrm{~h}$ relative to intake $\%$ : SNat 92.8; LC 82.7; HL 78.7; HA 76.0; HC 72.5; SHyd 71.3). The absorbed energy supply resulting from the VFA increased accordingly, in the presence of poorly digestible or indigestible carbohydrates (as a percentage of the total energy absorbed as RS, lactic acid (LA) and VFA: SNat 3.4; LC 7.1; HL 8.9; HC 10.4; SHyd 13.1) with one exception (HA: 6.0\%). For all diets, the greatest energy absorption (42-63\% according to the diet) occurred during the first $4 \mathrm{~h}$ after the meal, the larger fraction resulting from RS (86.8-94.8\% according to the diet). The energy supply due to the absorption of VFA became large between the 5th and the 12th hour, and was larger for diets containing poorly digestible or indigestible carbohydrates (as a percentage of the total RS + LA + VFA: SNat 6.5; LC 8.7; HC 14.3; HC 14.4; SHyd 23.3) with one exception (HA: 9.0\%). Although the late absorption of VFA was insufficient to compensate for the energy deficit due to a lower of RS, it may bridge the energy gap during the interprandial period.
\end{abstract}

poorly digestible carbohydrate / indigestible carbohydrate / volatile fatty acid / reducing sugar / absorption / chronology / pig 
Résumé - Influence de la nature des glucides ingérés sur la chronologie de l'absorption des acides gras volatils chez le porc. Une analyse expérimentale de la chronologie de l'absorption d'énergie, selon qu'elle provient de la digestion enzymatique ou de la digestion microbienne, a été faite à partir de la comparaison des résultats de trois expériences successives réalisées chez le porc. Au cours de ces expériences, la chronologie de l'absorption des sucres réducteurs et de l'azote aminé, d'une part, et des acides gras volatils, d'autre part, a été étudiée après administration de régimes semi-synthétiques, bien équilibrés par ailleurs, contenant divers substrats connus pour n'être que peu (lactose) ou pas (cellulose pure) hydrolysés dans l'intestin grêle, ou faiblement absorbés (sorbitol) à ce niveau. Les régimes contenaient les substrats suivants : (Exp A) cellulose pure utilisée à deux taux (LC 6 $\%, H C 16 \%)$; (Exp B) farine de luzerne (22\%) permettant d'apporter $6 \%$ de cellulose (HA) versus lactose (22\%) en addition de $6 \%$ de cellulose pure ; (Exp C) sorbitol sous forme de maltitol (53\%) en addition de $6 \%$ de cellulose pure (SHyd) versus son homologue non hydrogéné, le maltose ( $53 \%$, SNat) dans les mêmes conditions. Chacun de ces régimes était administré à cinq porcs munis de cathéters placés dans la veine porte et l'artère carotide et d'une sonde débitmétrique autour de la veine porte, dispositif permettant de mesurer l'absorption postprandiale des nutriments. Dans ces conditions, après le dernier repas $(800 \mathrm{~g})$ pour un niveau d'ingéré de glucides non cellulosiques à peu près équivalent (2 190 à $2330 \mathrm{kcal}$, sauf HC $1930 \mathrm{kcal}$ ), l'énergie apparue sous forme de glucose pendant 12 heures dans le sang portal diminue relativement à l'énergie glucidique ingérée (\%) lorsque le taux de cellulose s'élève, ou lorsque des glucides peu digestibles (lactose, sorbitol) dans l'intestin grêle sont présents dans le régime (SNat 92,8\%; LC 82,7\%; HL 78,7\%; HA $76 \%$; HC 72,5\%; SHyd 71,3\%) ; l'apport énergétique provenant des AGV représente corrélativement un complément croissant à l'énergie absorbée sous forme de glucose et d'acide lactique (en \% du total : SNat 3,$4 ; L C 7,1 ; H L 8,9 ; H C$ 10,4; SHyd 13,1), une exception étant constituée par HA $(6,0 \%)$. Ce complément est cependant insuffisant pour compenser le déficit énergétique d'absorption de glucose. Pour tous les régimes, l'absorption la plus massive d'énergie ( 42 à $63 \%$ selon le régime) se situe au cours des quatre premières heures après le repas, l'énergie absorbée à cette période provenant majoritairement du glucose $(86,8$ à $94,8 \%$ selon le régime). À partir de la cinquième heure, la fraction provenant des acides gras volatils prend de l'importance relativement à l'énergie absorbée sous forme de glucose et d'acide lactique, ce phénomène étant plus marqué pour les régimes peu digérés dans l'intestin grêle (en $\%$ du total : SNat 6,5 ; LC 8,7; HL 14,3; HC 14,4; SHyd 23,3), une exception étant constituée par HA (9,0\%). Quoique insuffisante quantitativement, l'absorption tardive d'AGV peut ainsi constituer un relais énergétique pour la période interprandiale dont il serait intéressant d'analyser les conséquences.

glucides indigestibles ou peu digestibles / acides gras volatils / sucres réducteurs / absorption / chronologie / porc

\section{INTRODUCTION}

The amplitude and chronology of the breakdown of feeds in the pig's small intestine vary according to their composition and physicochemical nature. Thus, the residues from enzymatic digestion contain virtually all the fibrous carbohydrates initially present and various amounts of other carbohydrates and proteins. These residues reach the hindgut after a time lag that depends on their transit time and some of them act as substrates for the gut microflora which carry out anabolic (formation of microbial pro- teins) or catabolic (formation of amines, volatile fatty acids and various gases: $\mathrm{CO}_{2}$, $\mathrm{CH}_{4}, \mathrm{H}_{2}$ ) processes (Rérat, 1978, 1981a).

Variations in the quantities of organic acids along the pig's digestive tract have been well established in vivo. Only small amounts of these occur in the stomach and lactic acid accounts for over half the amount present (Étienne, 1969; Cranwell et al, 1976). The concentrations are low in the small intestine but increase suddenly in the caecum and even more so in the colon (Clemens et al, 1975) where they may reach $200 \mathrm{mmol} / \mathrm{L}$, ie, ten times as high as in the 
stomach. The concentrations in the hindgut vary widely according to the amount of time elapsed since the previous meal.

Volatile fatty acids (VFA) account for $98 \%$ of all organic acids occurring in the hindgut (Clemens et al, 1975). Their composition is usually a mixture of acetic, propionic and butyric acids $(55,34$ and $11 \%$, respectively, according to Argenzio and Southworth, 1975). Once the VFA production systems have reached full development, these proportions change very little with age (Kass et al, 1980).

The production of organic acids varies with the type and amount of carbohydrates in the diet. An increase in the dietary level of crude fibre in the pig usually increases the amount of VFA in the distal part of the digestive tract (Gargallo and Zimmerman, 1980; Kass et al, 1980; Stanogias and Pearce, 1985), although this is controversial (Argenzio and Southworth, 1975; Kennelly et al, 1981). The amount of fibre in the diet affects the composition of the VFA mixture, either by increasing (Kass et al, 1980) or by decreasing (Gargallo and Zimmerman, 1980) the amount of acetic acid at the expense of butyric and propionic acids. Oat bran results in a higher proportion of butyric acid in large intestinal content compared with an oat flour diet (Bach Knudsen et al, 1993). VFA production also depends on the type of starch in the diet and on how it has been processed. For instance, the intake of raw potato starch (Ledinek, 1970; Koch et al, 1972), which increases the amount of dry matter and starch in the hindgut compared with cooked potato starch, increases the amount of VFA produced but the VFA composition remains unchanged. Increasing the amount of molasses in the pigs' diet increases the VFA content, especially the acetate content (Ly, 1994). The conclusion resulting from these studies is that the amount and type of VFA produced in the hindgut varies according to the level of intake and diet composition.
The production of VFA is followed by absorption, as indicated by their presence in the portal blood (Topping et al, 1985) and quantified by measuring portal-arterial concentration differences and blood flow in the portal vein (Rérat et al, 1985, 1987; Yen et al, 1991).

In the pig, transport of VFA by the caecum and colon mucosae is faster than by the gastric mucosa: the absorption is efficient (Argenzio and Southworth, 1975) and complete (Farrell and Johnson, 1972). A VFA mixture appears along the various stages of the efferent intestinal blood and the concentrations are highest in the coecocolic blood (Barcroft et al, 1944). The VFA profile has been measured in the peripheral blood of pigs (McClymont, 1951), in the portal blood (Friend et al, 1964) and more recently in both the arterial and portal blood (Rérat et al, 1985; Topping et al, 1985; Yen et al, 1991). Significant amounts of these substances are used by the enterocytes for their own metabolic needs during transport (Ly, 1974; Imoto and Namioka, 1978a, b). Almost all of the propionic, butyric and valeric acids are taken up by the liver, which uses part of the acetic acid only (Giusi-Périer et al, 1989; Rérat et al, 1987, 1993). Lactic acid, which accounts for a large portion of the organic acids, is also absorbed in the hindgut, but at a lower rate than in the small intestine. In perfusion studies, its absorption was directly related to the lactate concentration in the perfusion solution and was not affected by a metabolic inhibitor (Heller and Kern, 1968). Although the amounts absorbed during the postprandial period are quite high $(20-30 \mathrm{~g}$ within $8 \mathrm{~h}$ according to Rérat et al, 1978), it should be borne in mind that part of the lactic acid is produced by the metabolism of the gut wall along the gastrointestinal tract (Windmueller and Spaeth, 1978). This is responsible for $76-88 \%$ of the lactic acid produced during the postprandial period and $59-72 \%$ during fasting, according to the diet (Rérat and Vaissade, 1993). 
Absorption of VFA along the digestive tract, like its production, depends on the frequency of meals (Rérat et al, 1987) and on the diet. This is demonstrated by calculating VFA balances in the portal blood (GiusiPérier et al, 1989; Rérat et al, 1993) following the intake of semi-synthetic diets containing substrates which are known to be poorly (lactose: Rérat et al, 1990) or not (fibre) hydrolysed or weakly absorbed (sorbitol: Rérat et al, 1991) in the small intestine. However, the cumulative absorption balances are insufficient for comparing the chronology of the VFA appearance in the portal blood to that of reducing sugars (RS) obtained by enzymatic hydrolysis of carbohydrates, either between similar diets or between different diets. This chronology may be important because VFA may contribute to the energy supply at a time when the intestinal digestion is no longer supplying $R S$.

For these reasons, the absorption balance studies carried out in pigs fed different diets which were likely to produce large ileal residues (lactose, cellulose, sorbitol: Giusi-Périer et al, 1989; Rérat et al, 1993) were revisited and completed with chronology studies on the absorption of VFA and $\mathrm{RS}$ and the resulting metabolizable energy.

\section{MATERIALS AND METHODS}

Three successive experiments $(A, B, C)$ were carried out (Giusi-Périer et al, 1989; Rérat et al 1993) in pigs whose portal vein and carotid artery were catheterized under anaesthesia and whose portal vein was fitted with a flow probe. This setup made it possible to calculate the postprandial appearance of nutrients in the portal blood (Rérat et al, 1980). The semi-synthetic diets were based on corn starch and were well balanced with respect to minerals and vitamins ( 3 and $1 \%$ of mineral and vitamin mixes, respectively). Peanut oil was added ( $5 \%$ in Experiments $A$ and $B$ ), $1.9 \%$ in Experiment $C$ ). The protein supply was fish meal in Experiments $A$ and $B$ (nitrogen content of the diet: $2.11-2.22 \%$ of the dry weight) and casein in Experiment $C$ (nitrogen content: $2.33 \%$ ). The fermentable substrates were: Experiment $A$ : two concentrations of purified cellulose (LC diet: $6 \%$, $\mathrm{HC}$ diet: $16 \%$ ); Experiment $B: 22 \%$ alfalfa meal providing $6 \%$ crude fibre (HA diet) vs $22 \%$ lactose and $6 \%$ purified cellulose ( $\mathrm{HL}$ diet); Experiment $C: 53 \%$ of maltitol, oside containing $44 \%$ of a weakly absorbed polyol, namely sorbitol (Rérat et al, 1991), in addition to 6\% purified cellulose (SHyd diet) vs maltose, which is a nonhydrogenated homologue of maltitol containing glucose only, used similarly (53 and 6\% purified cellulose: SNat diet). In each experiment, five animals (mean weight: Experiment $A 58.2 \pm 1.8 \mathrm{~kg}$; Experiment $B 56.6 \pm 2.9 \mathrm{~kg}$; Experiment $C 61 \pm$ $1.7 \mathrm{~kg}$ ) were acclimated over a period of 7 to 10 days (two meals of $800 \mathrm{~g}$ each per day) to either of two diets (Experiment A: LC vs HC; Experiment $B$ : HA vs HL; Experiment $C$. SHyd vs SNat) and after fasting for $19 \mathrm{~h}$ were fed at $0900 \mathrm{~h} \mathrm{a}$ final meal of the same diet $(800 \mathrm{~g})$. Blood samples were taken starting at the beginning of the meal (time $t_{0}$ ) and during the following $24 \mathrm{~h}$ (Experiments $A$ and $B$ ) or $12 \mathrm{~h}$ (Experiment $C$ ) either every $15 \mathrm{~min}$, every $30 \mathrm{~min}$ or every hour according to the time and nutrient under study. Portal blood flow was measured continually in order to calculate the balance of enzymatic digestion over $12 \mathrm{~h}$ (Experiments $A, B$ and $C$ ) or of microbial digestion over $24 \mathrm{~h}$ (Experiments $A$ and $B$ ) or 12 $\mathrm{h}$ (Experiment $C$ ). The diets were reversed at the end of the sampling period and each animal was acclimated to its new diet for $7-10$ days. The sampling and measurements were repeated as previously. In each experiment, the nature of the experiment diet used in the first trial was alternated from one animal to another so as to avoid interactions between treatment and time. The raw energy intake as non-fibrous carbohydrates was almost identical in all diets (LC 2 192; HA 2 214; HL 2 272; SHyd and SNat 2332 kcal) except for HC (1 934 kcal).

The blood parameters that were analysed included amino nitrogen (Palmer and Peters, 1966), glucose (glucose oxidase: Hill and Kessler, 1961), RS (Hoffman, 1937), lactic acid (Minaire et al, 1965), D-lactic acid (Gawehn and Bergmeyer, 1974), sorbitol (Bergmeyer et al, 1974) and VFA (Giusi, 1986: Giusi-Périer et al, 1989). The overall appearance of the nutrients and metabolites in the portal blood flow was calculated according to:

$$
q=(C p-C a) F d t
$$


and

$$
Q=\sum_{t n-1}^{t n-2} q
$$

where $q$ is the amount absorbed over a short period ( $d t=5 \mathrm{~min}$ ) during which all factors may be considered as constant, $C p$ is the concentration in the portal vein (expressed as $\mathrm{mg} / \mathrm{L}$ for glucose, amino nitrogen, sorbitol and lactic acid and as $\mu \mathrm{mol} / \mathrm{L}$ for VFA), $C a$ is the arterial concentration, $F$ the flow rate through the portal vein $(\mathrm{mL} / \mathrm{min})$ and $Q$ is the amount that appeared during defined periods after the meal (between times $t n-2$ and $t n-1)$. The amount of 'residues not absorbed within $12 \mathrm{~h}$ ' was estimated by subtracting the amount of RS and amino nitrogen ( $x$ 6.25) that appeared in the portal vein during the $12 \mathrm{~h}$ period from the amounts ingested. The values obtained provided some indication of the amount of ileal residues that might arise from each diet, although they were not strictly quantitative since digestion was not completely finished after $12 \mathrm{~h}$ and a large part of the nutrients were taken up by the gut wall during digestion (Rérat, 1981b).
Combustion heat data for individual VFA (Hodgman, 1959) was applied to the absorbed VFA mixture to calculate the metabolizable energy. Data from Schiemann et al (1971) were used for calculating the energy supplied by other nutrients. The same energy value was used for lactic acid as for starch (Charlet-Lery, 1964).

\section{RESULTS}

The overall balance of the first $12 \mathrm{~h}$ period of digestion after intake is indicated in table I. For a similar intake of non-fibrous carbohydrates, increasing the fibre content of the diet or introducing osides, which are weakly hydrolysed in the small intestine (lactose), or that contain (maltitol) a polyol which is weakly absorbed there (sorbitol) decreased the amount of RS that appeared in the portal vein. This was demonstrated by changes in the absorption coefficient over the $12 \mathrm{~h}$ period (amount of RS that

Table I. Amounts of nutrients and metabolites appearing in the portal blood during the $12 \mathrm{~h}$ period after intake $(800 \mathrm{~g})$ of diets containing several types of poorly digestible or undigestible carbohydrates in the pig.

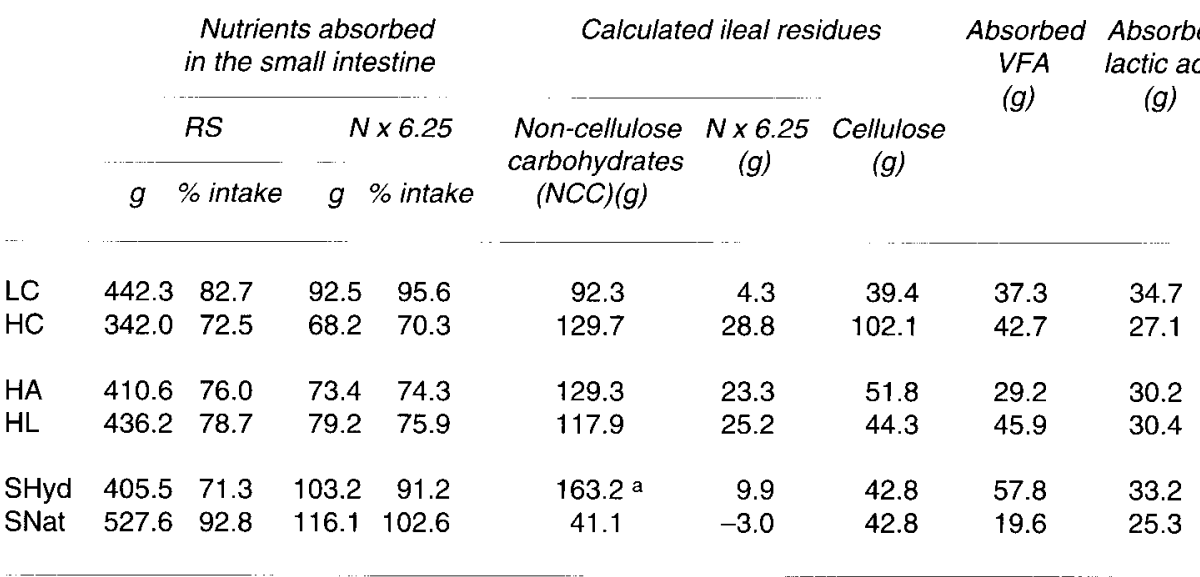

a Sorbitol: $132 \mathrm{~g}$. Semi-synthetic diets containing (intake (g)): LC $6 \%$ purified cellulose NCC $=534.6, \mathrm{~N} \times 6.25=$ 96.8; HC $16 \%$ purified cellulose $\mathrm{NCC}=471.7, \mathrm{~N} \times 6.25=97.0 ; \mathrm{HA} 22 \%$ alfalfa meal (ie, $6 \%$ crude fibre) $\mathrm{NCC}=$ $539.9, \mathrm{~N} \times 6.25=98.7 ; \mathrm{HL} 22 \%$ lactose $+6 \%$ purified cellulose $\mathrm{NCC}=554.1, \mathrm{~N} \times 6.25=106.4 ; \mathrm{SHyd} 53 \%$ maltitol $+6 \%$ purified cellulose $\mathrm{NCC}=568.7, \mathrm{~N} \times 6.25=113.1$; SNat $53 \%$ maltose $+6 \%$ purified cellulose NCC $=$ $568.7, \mathrm{~N} \times 6.25=113.1$. NCC by difference $(\mathrm{g}): \mathrm{DM}-(\mathrm{N} \times 6.25$ + lipids + crude fiber + minerals $)$. 
appeared in the portal vein as a percentage of the amount of non-fibrous carbohydrates ingested: SNat 92.8; LC 82.7; HL 78.7; HA 76.0; HC 72.5; SHyd 71.3). The changes affecting the total estimated amounts (g) of non-fibrous carbohydrates, which were not absorbed within $12 \mathrm{~h}$, were in the opposite direction. The amounts of VFA absorbed (g) during the same period were usually proportional to these residues, except in the HA diet, where the amount of VFA production was quite small compared to the amount of non-fibrous carbohydrate residues. The amount of lactic acid absorbed varied between 25 and $35 \mathrm{~g} / 12 \mathrm{~h}$, although these variations could not be related to the amount of non-absorbed residues. In the maltose (SNat) and maltitol (SHyd) diets, the only diets in which $D$ and $L$ forms were analysed separately, almost all the lactic acid (averaging 95\% over $12 \mathrm{~h}$ ) occurred as the $\mathrm{L}$ isomer.

The absorbed VFA profile was only slightly affected by the ingested diet (table II), except for the SHyd diet. In this diet, the large estimated amounts of sorbitol residues $(132 \mathrm{~g})$ in the gut produced a large amount of propionic acid, thereby increasing both the energy value of VFA mixture absorbed as well as its amount.

Table III shows the various forms of metabolizable energy (RS, lactic acid, VFA) that appeared in the portal blood during the postprandial period (0-12 h). Most of the energy absorbed within the $12 \mathrm{~h}$ period occurred as RS (between $92.2 \%$ in SNat and $80.3 \%$ in SHyd). The percentage of absorbed energy occurring as VFA (SNat 3.4; LC 7.1; HL 8.9; HC 10.4; SHyd 13.1) was proportional to the estimated amount of non-absorbed residues except in the HA diet (6.0), whereas that occurring as lactic acid was far more constant (LC 6.7; HL 5.9; HC 6.6; SHyd 6.6; HA 6.4) except in the SNat diet, which contained a high amount of digestible energy and in which slightly less lactic acid was produced $(4.4 \%)$. It should be stressed, however, that the absorption of VFA and lactic acid did not compensate over the $12 \mathrm{~h}$ for the RS absorption deficit in the small intestine, except in the starch-based diet with a low fibre content (LC) or in the maltose-based $\operatorname{diet}$ (SNat).

Table II. Distribution of individual VFA (\%) within the mixture of absorbed total VFA for a period of $12 \mathrm{~h}$ after intake of semi-synthetic diets containing several types of poorly digestible or undigestible carbohydrates in the pig.

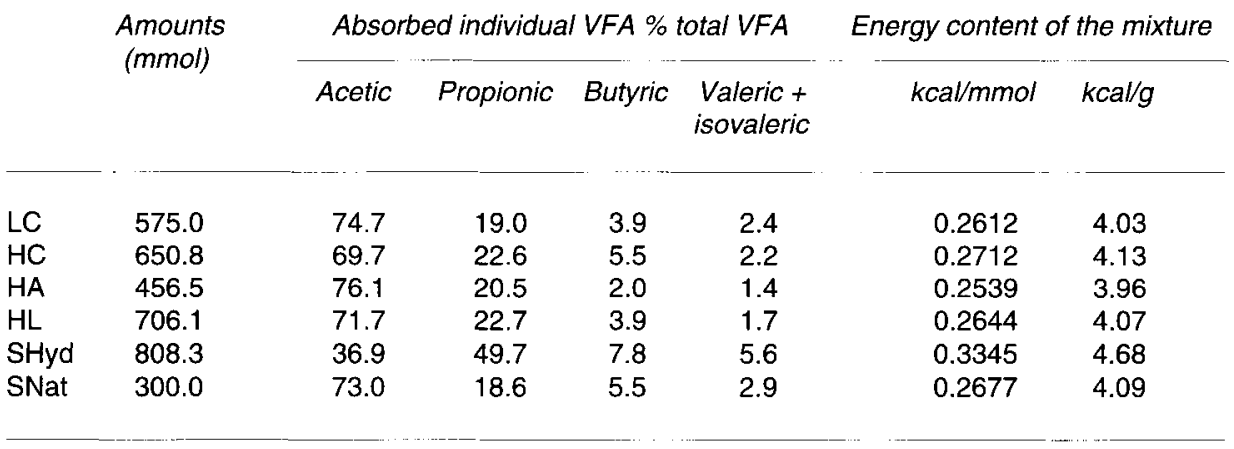

Semi-synthetic diets containing: LC 6\% purified cellulose; HC $16 \%$ purified cellulose; HA $22 \%$ alfalfa meal (ie, $6 \%$ crude fibre); HL $22 \%$ lactose $+6 \%$ purified cellulose; SHyd $53 \%$ maltitol $+6 \%$ purified cellulose; SNat $53 \%$ maltose $+6 \%$ purified cellulose. 
Table III. Energy (kcal/12 h) appearing in the portal blood under different forms (RS, VFA, lactic acid) during the $12 \mathrm{~h}$ period after intake of the same amount $(800 \mathrm{~g})$ of diets containing several types of poorly digestible or undigestible carbohydrates in the pig.

\begin{tabular}{|c|c|c|c|c|c|c|}
\hline \multirow{2}{*}{\multicolumn{2}{|c|}{$\begin{array}{c}\text { Energy intake } \\
\left(E_{i}\right) \text { as non-cellulosic } \\
\text { carbohydrates } \\
(\text { kcal })\end{array}$}} & \multicolumn{4}{|c|}{ Energy absorbed as } & \multirow{2}{*}{$\begin{array}{c}\text { Energy absorbed } \\
\text { (T) } \% E_{i}\end{array}$} \\
\hline & & $\begin{array}{c}R S \\
(k c a l)\end{array}$ & $\begin{array}{r}V F A \\
(\mathrm{kcal})\end{array}$ & $\begin{array}{l}\text { Lactic acid } \\
\quad(\text { kcal })\end{array}$ & $\begin{array}{c}\text { Total }(T) \\
(\text { kcal })\end{array}$ & \\
\hline LC & 2192 & 1813.4 & 150.2 & 142.2 & 2105.8 & 96.1 \\
\hline $\mathrm{HC}$ & 1934 & 1402.4 & 176.5 & 111.0 & 1689.9 & 87.4 \\
\hline $\mathrm{HA}$ & 2214 & 1683.5 & 115.9 & 123.7 & 1923.0 & 86.9 \\
\hline $\mathrm{HL}$ & 2272 & 1788.5 & 186.7 & 124.7 & 2099.9 & 92.4 \\
\hline SHyd & 2332 & 1662.5 & 270.5 & 136.0 & 2069.0 & 88.7 \\
\hline SNat & 2332 & 2163.2 & 80.3 & 103.8 & 2347.3 & 100.5 \\
\hline
\end{tabular}

Semi-synthetic diets containing: LC 6\% purified cellulose; HC 16\% purified cellulose; HA $22 \%$ alfalfa meal (ie, $6 \%$ crude fibre); HL $22 \%$ lactose $+6 \%$ purified cellulose; SHyd $53 \%$ maltitol $+6 \%$ purified cellulose; SNat $53 \%$ maltose $+6 \%$ purified cellulose

The concentration curves (Giusi-Périer et al, 1989; Rérat et al, 1993) show that differences between the RS contents of portal and arterial blood were the largest during the first few hours following intake, corresponding to the peak absorption period (figs $1-3)$. However, the differences in the VFA concentrations occurred later. Maximum values were reached between 6 and $24 \mathrm{~h}$ after the meal in the starch-rich diets (LC and $H C$ ), between 3 and $10 \mathrm{~h}$ in the lactose-based diet (HL) and between 4 and 12 $\mathrm{h}$ in the maltitol-based diet (SHyd). In the SHyd diet, the differences between portal and arterial blood remained three times as high $12 \mathrm{~h}$ after the meal as at $1 \mathrm{~h}$, suggesting that the values would remain high during the hours that followed. In order to take into account these differences in the chronology of RS and VFA absorption, the postprandial period $(0-12 \mathrm{~h})$ was arbitrarily divided into two subperiods $(0-4 \mathrm{~h}$ and $5-12$ h) for analysing the absorption of the various forms of metabolizable energy.

The total energy absorption rate was higher during the first $4 \mathrm{~h}$ after the meal than during the following period (5-12 h) (table IV). Depending on the diet, $41.8 \%$ (LC), $47.9 \%$ (HC), $52.7 \%$ (HA), 53.5\% (HL), $53.7 \%$ (SHyd) or $62.5 \%$ (SNat) of the total energy absorption (0-12 h) occurred during the first $4 \mathrm{~h}$. This was largely due to the early absorption of RS whose absorption rates were 127 to $193 \%$ as high as during the whole period $(0-12 h)$ and varied widely between diets (table V). RS absorption appeared the latest under starch-rich diets ( $\mathrm{LC}$ and $\mathrm{HC}$ ) and the earliest under diets with a high maltose content (SNat) and to a lesser extent the maltitol (SHyd) diet. Alfalfa and lactose-rich diets came somewhere in between. On the other hand, the energy absorption rates in the form of VFA were only $84-88 \%$ as high as the average value over the whole postprandial period $(0-12 \mathrm{~h})$ under most diets (LC, HC, HA, SNat), lower still under the $\mathrm{HL}$ diet $(75 \%)$ and even less under the SHyd diet (52.0\%) highlighting the late appearance of VFA. Finally, lactic acid was absorbed at a much higher rate during the first $4 \mathrm{~h}$ than afterwards, since the energy absorption rates in the form of 

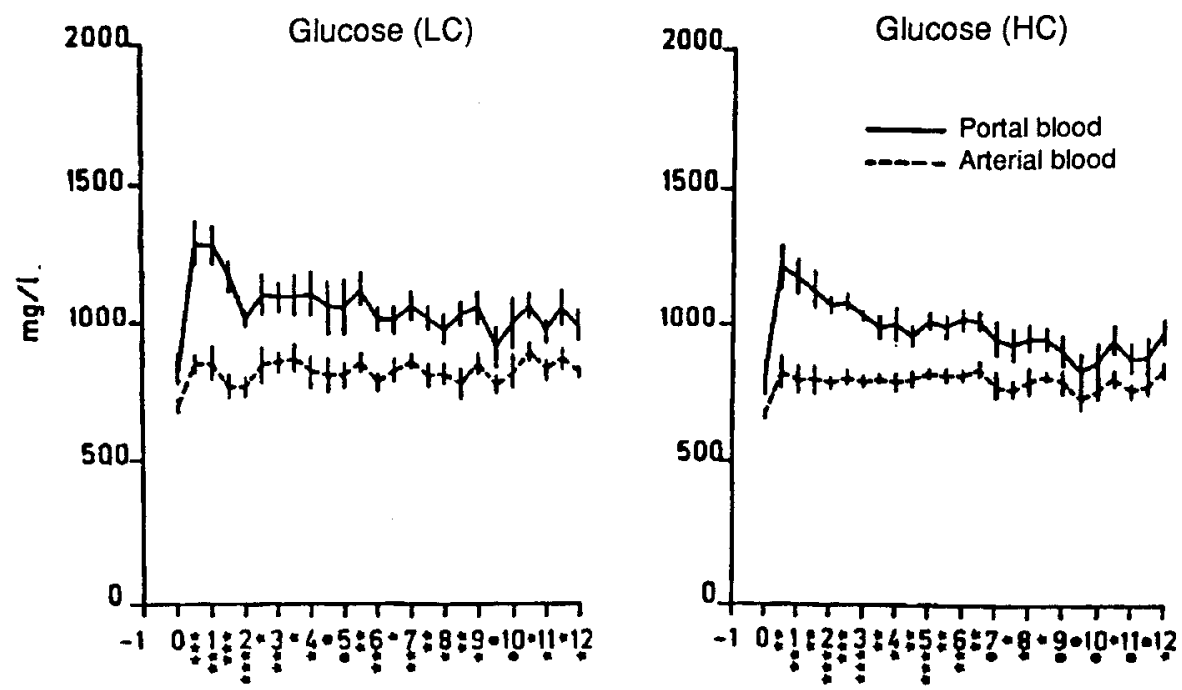

Time elapsed after the meal $(h)$
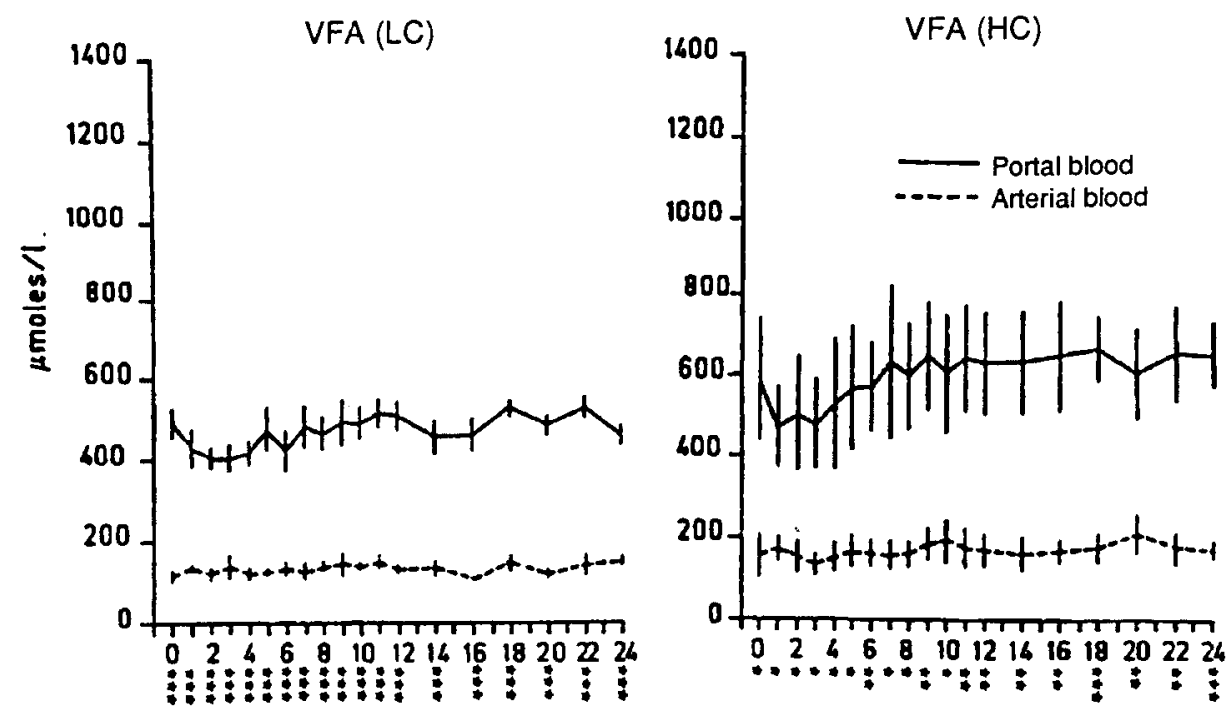

Time elapsed after the meal (h)

Fig 1. Portal and arterial concentrations of glucose and VFA after the intake of semi-synthetic diets containing $6 \%(\mathrm{LC})$ or $16 \%(\mathrm{HC})$ pure cellulose. Five animals per diet. Vertical lines indicate standard errors of the mean. Difference between portal and arterial blood: $P>0.05,{ }^{\star} P<0.05,{ }^{\star \star} P<0.01$, $\star \star \star *<0.001$. 

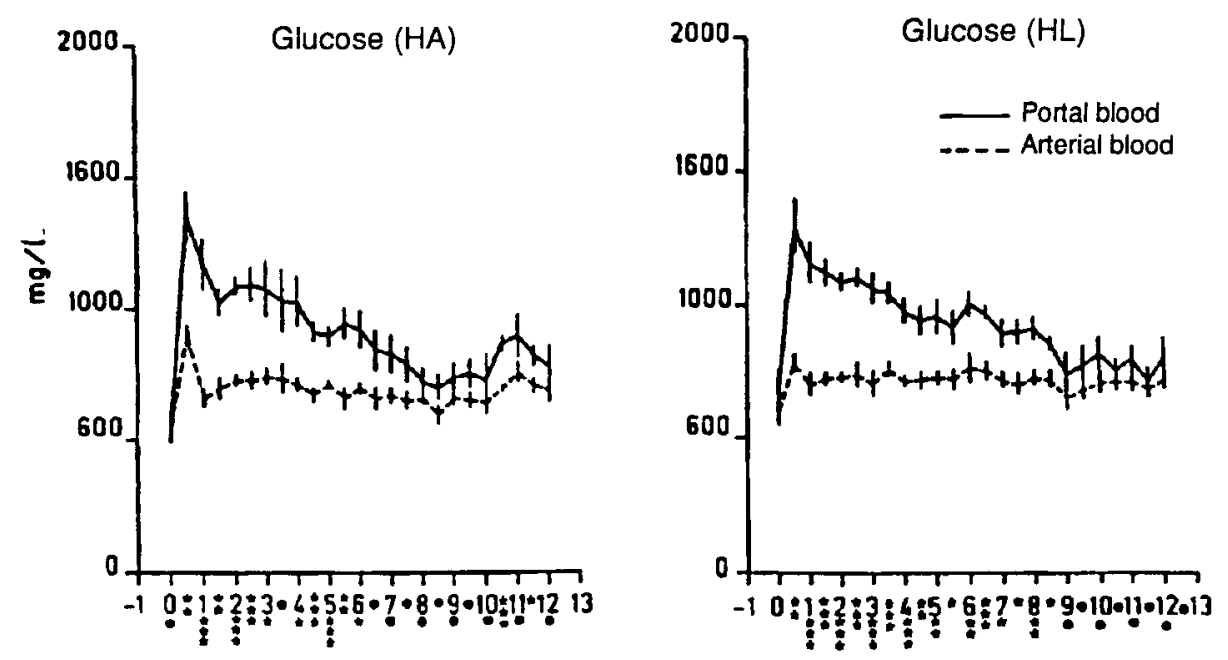

Time elapsed after the meal (h)
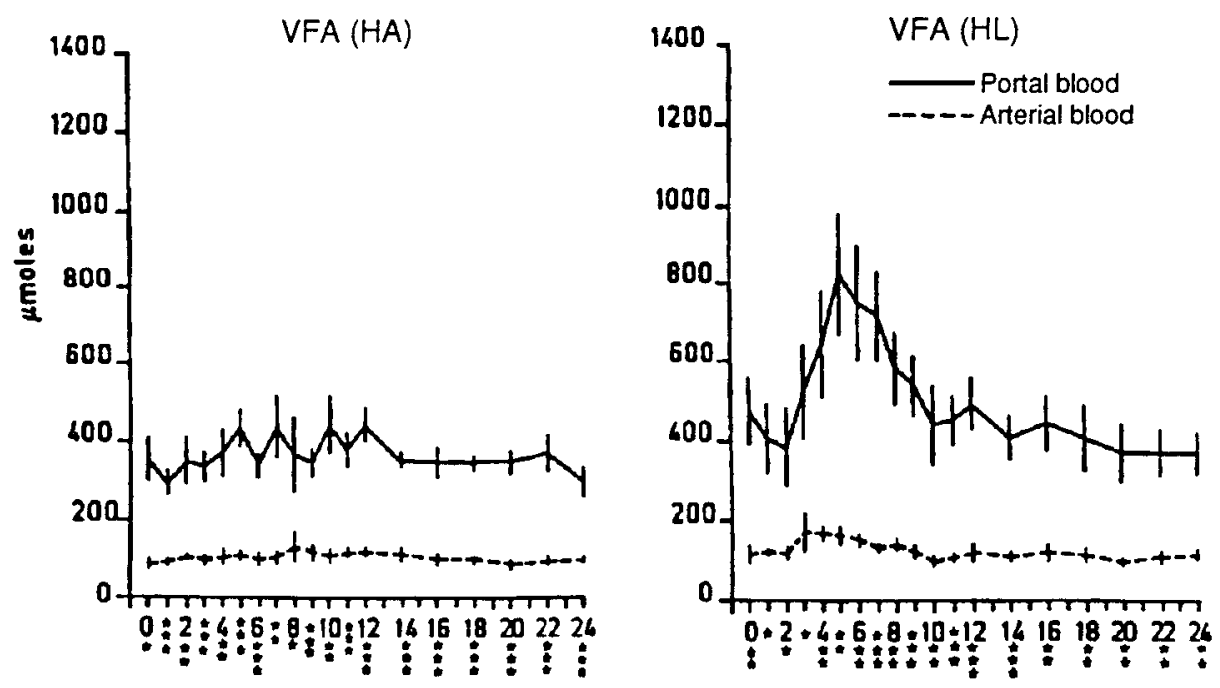

Time elapsed after the meal (h)

Fig 2. Portal and arterial concentrations of glucose and VFA after the intake of semi-synthetic diets containing $22 \%$ alfalfa meal $(\mathrm{HA})$ or lactose $(\mathrm{HL})$. Five animals per diet. Vertical lines indicate standard errors of the mean. Difference between portal and arterial blood: $\bullet P>0.05,{ }^{\star} P<0.05,{ }^{\star \star} P<0.01$, ${ }^{\star \star \star *} P<0.001$. 

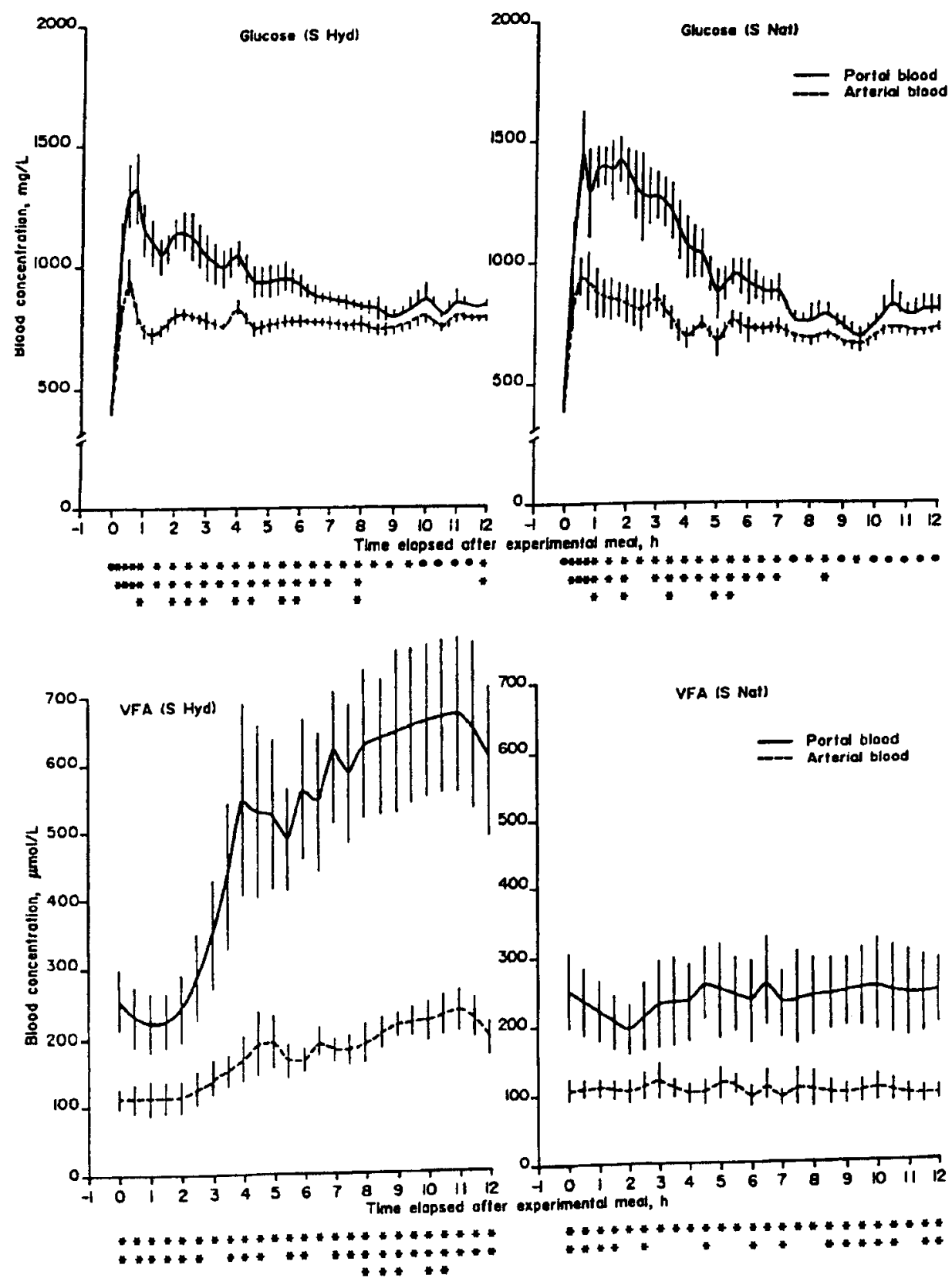

Fig 3. Portal and arterial concentrations of glucose and VFA after the intake of semi-synthetic diets containing $53 \% \mathrm{DM}$ of a maltose-rich glucose syrup (SNat) or a maltitol-rich hydrogenated glucose syrup (SHyd). Five animals per diet. Vertical bars indicate standard errors of the mean. Difference between portal and arterial blood: $\bullet P>0.05,{ }^{\star} P<0.05,{ }^{\star \star} P<0.01,{ }^{\star \star \star} P<0.001$. 
Table IV. Energy (kcal/h) appearing in the portal blood under different forms (RS, VFA, lactic acid) during the first $4 \mathrm{~h}(0-4 \mathrm{~h})$, and the following period $(5-12 \mathrm{~h})$ after intake of the same amount (800 g) of diets containing several types of poorly digestible or undigestible carbohydrates in the pig.

\begin{tabular}{|c|c|c|c|c|c|c|c|c|}
\hline & \multicolumn{4}{|c|}{ Energy absorbed during the period $0-4 h$ as } & \multicolumn{4}{|c|}{ Energy absorbed during the period $5-12 \mathrm{~h}$ as } \\
\hline & $R S$ & $V F A$ & Lactic acid & Total & $R S$ & $V F A$ & Lactic acid & Total \\
\hline LC & 191.3 & 10.8 & 18.1 & 220.2 & 131.0 & 13.4 & 8.7 & 153.0 \\
\hline $\mathrm{HC}$ & 175.7 & 12.4 & 14.4 & 202.5 & 87.5 & 15.8 & 6.7 & 109.9 \\
\hline $\mathrm{HA}$ & 225.7 & 8.6 & 18.9 & 253.2 & 97.6 & 10.2 & 6.0 & 113.8 \\
\hline $\mathrm{HL}$ & 250.6 & 11.7 & 18.4 & 280.6 & 98.3 & 17.5 & 6.4 & 122.2 \\
\hline SHyd & 248.6 & 11.7 & 17.2 & 277.6 & 83.5 & 27.9 & 8.4 & 119.9 \\
\hline SNat & 347.9 & 5.9 & 13.3 & 367.1 & 96.5 & 7.1 & 6.3 & 109.9 \\
\hline
\end{tabular}

Semi-synthetic diets containing: LC $6 \%$ purified cellulose; HC $16 \%$ purified cellulose; HA $22 \%$ alfalfa meal (ie, $6 \%$ crude fibre); HL $22 \%$ lactose $+6 \%$ purified cellulose; SHyd $53 \%$ maltitol $+6 \%$ purified cellulose; $\mathrm{SNat} 53 \%$ maltose $+6 \%$ purified cellulose.

lactic acid during the first subperiod were from 152 to $156 \%$ (LC, HC, SHyd, SNat) as high as the average value over the whole preprandial period, reaching as much as 183 and $177 \%$ under the $\mathrm{HA}$ and $\mathrm{HL}$ diets, respectively. Virtually all the lactic acid occurred as the $L$ isomer in the experiment where the $L$ and $D$ isomers were analysed separately (SNat $96 \%$; SHyd $97 \%$ ). During early absorption, most of the energy

Table V. Energy absorbed per hour under different forms (RS, VFA, lactic acid) during the first $4 \mathrm{~h}$ $(0-4 \mathrm{~h})$ and the following period $(5-12 \mathrm{~h})$ after intake of the same amount $(800 \mathrm{~g})$ of diets containing different poorly digestible or undigestible carbohydrates in the pig.

\begin{tabular}{|c|c|c|c|c|c|c|c|c|}
\hline & \multicolumn{4}{|c|}{$\begin{array}{l}\text { Energy absorbed per hour } \\
\text { during the period } 0-4 \mathrm{~h}\end{array}$} & \multicolumn{4}{|c|}{$\begin{array}{l}\text { Energy absorbed per hour } \\
\text { during the period } 5-12 \mathrm{~h}\end{array}$} \\
\hline & $R S$ & $V F A$ & Lactic acid & Total & RS & $V F A$ & Lactic acid & Total \\
\hline LC & 126.6 & 86.4 & 152.1 & 125.5 & 86.7 & 107.2 & 73.1 & 87.2 \\
\hline $\mathrm{HC}$ & 150.3 & 84.3 & 156.5 & 143.8 & 74.8 & 107.5 & 72.8 & 78.1 \\
\hline $\mathrm{HA}$ & 160.8 & 88.7 & 183.5 & 158.0 & 69.6 & 105.2 & 58.2 & 71.0 \\
\hline $\mathrm{HL}$ & 168.2 & 75.0 & 176.9 & 160.4 & 66.0 & 112.2 & 61.5 & 69.9 \\
\hline SHyd & 179.5 & 52.0 & 152.2 & 161.0 & 60.3 & 124.0 & 74.3 & 69.6 \\
\hline SNat & 193.0 & 88.1 & 152.9 & 187.8 & 53.5 & 106.0 & 72.4 & 56.2 \\
\hline
\end{tabular}

Expressed as a percentage of the hourly absorption during the whole postprandial period $(0-12 \mathrm{~h})$. Semisynthetic diets containing: LC $6 \%$ purified cellulose; HC $16 \%$ purified cellulose; HA $22 \%$ alfalfa meal (ie, $6 \%$ crude fibre); HL 22\% lactose $+6 \%$ purified cellulose; SHyd 53\% maltitol $+6 \%$ purified cellulose; SNat $53 \%$ maltose + $6 \%$ purified cellulose. 
Table VI. Contribution (\%) of the different nutrients and metabolites (RS, VFA, lactic acid) in the total energy absorbed during the first $4 \mathrm{~h}(0-4 \mathrm{~h})$ and the following period $(5-12 \mathrm{~h})$ after intake of the same amount $(800 \mathrm{~g})$ of diets containing several types of poorly digestible or undigestible carbohydrates in the pig.

\begin{tabular}{|c|c|c|c|c|c|c|c|}
\hline \multicolumn{4}{|c|}{ First period ( $0-4 \mathrm{~h}$ after the meal) } & \multicolumn{4}{|c|}{ Second period (5-12 $h$ after the meal) } \\
\hline $\begin{array}{l}R S \\
(\%)\end{array}$ & $\begin{array}{l}\text { VFA } \\
(\%)\end{array}$ & $\begin{array}{c}\text { Lactic acid } \\
(\%)\end{array}$ & $\begin{array}{c}\text { Total } \\
\text { (kcal) }\end{array}$ & $\begin{array}{l}R S \\
(\%)\end{array}$ & $\begin{array}{l}\text { VFA } \\
(\%)\end{array}$ & $\begin{array}{l}\text { Lactic acid } \\
\quad(\%)\end{array}$ & $\begin{array}{l}\text { Total } \\
\text { (kcal) }\end{array}$ \\
\hline 86.9 & 4.9 & 8.2 & 881.0 & 85.6 & 8.7 & 5.7 & 1224.8 \\
\hline 86.8 & 6.1 & 7.1 & 810.2 & 79.5 & 14.4 & 6.1 & 879.7 \\
\hline 89.2 & 3.4 & 7.5 & 1012.6 & 85.7 & 9.0 & 5.3 & 910.4 \\
\hline 89.3 & 4.2 & 6.5 & 1122.4 & 80.4 & 14.3 & 5.2 & 977.5 \\
\hline 89.6 & 4.2 & 6.2 & 1110.1 & 69.7 & 23.3 & 7.0 & 958.9 \\
\hline 94.8 & 1.6 & 3.6 & 1468.2 & 87.8 & 6.5 & 5.7 & 879.1 \\
\hline
\end{tabular}

Semi-synthetic diets containing: LC 6\% purified cellulose; HC 16\% purified cellulose; HA $22 \%$ alfalfa meal (ie, $6 \%$ crude fibre); $\mathrm{HL} 22 \%$ lactose $+6 \%$ purified cellulose; SHyd $53 \%$ maltitol $+6 \%$ purified cellulose; SNat $53 \%$ maltose $+6 \%$ purified cellulose.

occurred as RS (table VI). The RS contribution was the highest with the maltosebased diet (SNat) and the lowest with the starch-based diets ( $\mathrm{LC}, \mathrm{HC})$; the other three diets lie in between (HA, HL, SHyd). At the other end of the scale, the energy contribution of VFA was very low and varied between $1.6 \%$ with the highly energetic

Table VII. Contribution (\%) of the different nutrients and metabolites (RS, VFA, lactic acid) in the total energy absorbed during the 11th and 12th hour after intake of the same amount $(800 \mathrm{~g})$ of diets containing several types of poorly digestible or undigestible carbohydrates in the pig.

\begin{tabular}{|c|c|c|c|c|c|}
\hline & \multicolumn{3}{|c|}{ Energy absorbed as } & \multirow{2}{*}{$\begin{array}{c}\text { Total } \\
(11+12 \text { hour }) \\
\text { kcal }\end{array}$} & \multirow{2}{*}{$\begin{array}{c}\text { Total } \\
(11+12 \text { hour }) \\
\%(0-12 h)\end{array}$} \\
\hline & $R S(\%)$ & VFA (\%) & Lactic acid (\%) & & \\
\hline LC & 83.8 & 10.7 & 5.4 & 260.5 & 12.4 \\
\hline $\mathrm{HC}$ & 75.4 & 18.7 & 5.9 & 178.4 & 10.6 \\
\hline $\mathrm{HA}$ & 83.1 & 11.2 & 5.8 & 189.1 & 9.8 \\
\hline HL & 72.5 & 23.1 & 4.3 & 106.0 & 5.0 \\
\hline SHyd & 48.6 & 43.1 & 8.3 & 138.1 & 6.7 \\
\hline SNat & 79.0 & 12.4 & 8.6 & 116.8 & 5.0 \\
\hline
\end{tabular}

Semi-synthetic diets containing: LC $6 \%$ purified cellulose; HC 16\% purified cellulose; HA 22\% alfalfa meal (ie, $6 \%$ crude fibre); $\mathrm{HL} 22 \%$ lactose $+6 \%$ purified cellulose; SHyd $53 \%$ maltitol $+6 \%$ purified cellulose; SNat $53 \%$ maltose $+6 \%$ purified cellulose. 
SNat diet to $6.1 \%$ with the fibrous $\mathrm{HC}$ diets; the other four diets lie in between at below $5 \%$. Lactic acid generally accounted for more energy than the VFA (6.2-8.2\%) except with the highly energetic SNat diet $(3.6 \%)$.

Data analysis for the period between 5 and $12 \mathrm{~h}$ after the meal (tables IV and V) revealed several facts. First, the rate of RS absorption was quite low. It was the lowest with the maltitol - or maltose based diets (SHyd, SNat) and the highest with the starch-based diets (LC, HC). Secondly, the absorption rate of VFA was higher than during the first subperiod, especially with the diets with high maltose (SHyd), and to a lesser extent lactose (HL), contents. Lactic acid was also absorbed at a much lower rate than during the first subperiod, especially for the alfalfa-rich (HA) and lactose-rich $(\mathrm{HL})$ diets. The contribution of RS to the overall energy budget (table VI) tended to be lower than during the initial subperiod. It was the highest for the maltose-rich (SNat) and starch-rich (LC) diets and the lowest for the maltitol-based diet (SHyd). On the other hand, the VFA contributed far more energy than during the initial subperiod. This contribution was particularly high with the maltitol-based SHyd diet, remained high for diets with high fibre $(\mathrm{HC})$ or lactose $(\mathrm{HL})$ contents, and was poor for diets based on starch (LC) or maltose (SNat). Finally, lactic acid contributed between 5.2 and $7 \%$ of the energy during the second subperiod.

The increase in the energy contribution of VFA as postprandial time elapsed becomes even clearer when the average values computed over the 11th and 12th hours after the meal are considered (table VII). The contribution of VFA to the decreasing energy supply then becomes $43.1,23.1$ and $18.7 \%$ in the diets with high maltitol, lactose and fibre contents, respectively.

\section{DISCUSSION}

It should first be stressed that calculating a full digestion balance after an experimental meal is very difficult because of methodological and practical limitations. The main methodological limitation is due to uptake by the gut wall. In the pig, for instance, uptake of dietary glucose by the enterocyte varies between $7.5 \mathrm{~g} / \mathrm{h}$ (Rérat et al, 1990) and 13-17 g/h (Rérat et al, 1992). Uptake by the gut wall also accounts for much of the nitrogen absorption (as much as 30-44\%: Rérat, 1988; Rérat et al, 1992). Similarly, the VFA uptake may be as high as $0.90 \mu \mathrm{mol}$ per $\mathrm{g}$ of intestinal tissue (Ly, 1974). The main practical limitation is the length of time the blood sampling period can last. Digestion of diets containing large amounts of starch or other complex carbohydrates by the small intestine may last as long as 15-18 $\mathrm{h}$ after the meal (Rérat, 1982). Similarly, the transit time in the hindgut of a pig lasts $29 \mathrm{~h}$ on average (Hecker and Grovum, 1975). Appropriate experiments for obtaining quantified absorption balances after an experimental meal would have to last $18 \mathrm{~h}$ in order to study the nutrients derived from enzymatic digestion and 48-50 $\mathrm{h}$ for the bacterial metabolites. However, differences between the concentration curves of RS and amino nitrogen in portal and arterial blood become small as early as after $12 \mathrm{~h}$. On the other hand, the differences in the VFA curves reach their maximum before $12 \mathrm{~h}$ only under some diets (LC, HL, HA, SNat). Under the maltitolbased SHyd diet, the differences become maximum $12 \mathrm{~h}$ after the meal, whilst under the cellulose-rich $\mathrm{HC}$ diet, they increase by $20 \%$ after $12 \mathrm{~h}$ (Giusi-Périer et al, 1989; Rérat et al, 1993). A comparison period of $12 \mathrm{~h}$ is, therefore, too short for quantifying the relationship between VFA production and the percentage of material that goes undigested, since both are underestimated. Finally, in addition to VFA, other microbial 
metabolites $\left(\mathrm{H}_{2}, \mathrm{CH}_{4}, \mathrm{CO}_{2}\right)$ are produced, which were not measured. Moreover, one should bear in mind that the carbohydrate intake is not the only source of microbial metabolites. Some are produced from undigested exogenous and endogenous residues containing nitrogen. Because of these limitations, it was not possible to quantify the relationship between the carbohydrate residues of enzymatic digestion and VFA absorption. Nevertheless, general trends could be observed.

One of the advantages of the method, however, is that the chronology of nutrient and metabolite absorption can be compared between diets, and the first $12 \mathrm{~h}$ after the meal are particularly interesting in this respect. Studies on this period enable one to examine the complementary energy supply resulting from the absorption of nutrients derived from digestion and from the absorption of metabolites derived from fermentations, under normal feeding conditions with two meals per day.

Briefly, it should be stressed that VFA and lactic acid contributed poorly to the energy supply and did not compensate for the energy absorption deficit caused by the presence of carbohydrates that are weakly digested or absorbed in the small intestine. In addition, the low energy supply of VFA was partly due to the preliminary fasting duration (19 h). It is known that fermentation in the hindgut results from the residues of several previous meals in addition to those from the last meal (Hecker and Grovum, 1975). Leaving out one meal therefore depresses the basal VFA production rate (Rérat et al, 1987). However, this does not explain why the VFA absorption was poorer than in previous experiments performed after $24 \mathrm{~h}$ of fasting (Rérat et al, 1987; Yen et al, 1991). This divergence probably appeared because semi-synthetic diets were used in the present study, whereas Rérat et al (1987) and Yen et al (1991) used natural diets con- taining corn and soybean, which were thus more likely to ferment. In the best case (maltitol-based diet), VFA accounted for as little as $0.36 \mathrm{kcal} / \mathrm{h} / \mathrm{kg}$ body weight (vs $0.65 \mathrm{kcal} / \mathrm{h} / \mathrm{kg}$ body weight in Yen et al, 1991). Assuming that total heat production is $2.70 \mathrm{kcal} / \mathrm{h} / \mathrm{kg}$ body weight ( $Y$ en et al, 1991 ), then VFA contributed $13.9 \%$ of the total heat produced during the first $12 \mathrm{~h}$ after a meal under the maltitol-based diet (vs 23.8\% under a corn/soybean diet; Yen et al, 1991).

Several points regarding differences in the chronology of absorption between RS and VFA are worth mentioning.

Energy absorption was an early largescale process and was mainly due to the absorption of RS. Carbohydrates were enzymatically digested during the very first hours following a meal. Earliness varied, however, according to the dietary origin of the carbohydrates. Energy absorption in the form of RS was the fastest under the maltose-based diet and to some extent the maltitol-based diet, and the slowest in the starch-rich diets, with diets based on alfalfa and lactose coming somewhere in between. This order is the same as that observed with glucose, sucrose, lactose and starch (Rérat et al, 1984). These differences probably depend on how the diet affects the length of gastric emptying, on the hydrolysation speed of the molecules according to their complexity (starch vs maltose), and on the nature and amount of enzyme secretion (amylase vs maltase). Lactic acid also appeared early within the portal blood but provided far less energy than RS. In the experiment where the $D$ and $L$ isomers were analysed separately, almost all the lactic acid was L-lactic acid, which agrees with previous experiments where most (87-93\%) of the lactic acid absorbed during the first $5 \mathrm{~h}$ after the intake of a diet containing corn starch and fish meal was L-lactic acid (Rérat and Vaissade, 1993). Since D-lactic acid is produced by microbial fermentation only (Giesecke 
and Stangassinger, 1980), virtually all the lactic acid that appeared in the portal blood had a metabolic origin. Its absorption can be related to the secretory, motor and absorptive activities of the digestive tract, which are very intense during the first hours following a meal.

Another point is that not much VFA was formed or absorbed during the first $4 \mathrm{~h}$ after a meal. The small amounts that appeared were due to the fermentation of residues from previous meals. Leaving out one of the previous meals further reduces the amount of VFA formed (Rérat et al, 1987). VFA, therefore, contributed little to the total energy supply: $1.6 \%$ with the highly digestible maltose-based diet (SNat) to $6.1 \%$ with the starchy diet with a high cellulose content (HC).

Later, from $5 \mathrm{~h}$ after a meal and onwards, when the absorption of RS and lactic acid was greatly reduced, increasingly large amounts of VFA appeared in the portal blood, to an extent that was dependent on the diet. The VFA contribution to the energy supply, which was minor with highly digestible diets based on maltose (SNat) or with a high starch content (LC), was quite large for diets containing large amounts of lactose $(14.4 \%)$, pure fibre $(14.3 \%)$ or maltitol $(23.3 \%)$, whose sorbitol fraction is only weakly absorbed by the small intestine. These last three diets introduced large amounts of non-fibrous, easily fermentable material into the hindgut, which explained their high rate of late VFA appearance, although the exact relationship between the two factors cannot be established for the reasons mentioned above.

The energy supply from the digestive tract was thus a two-phase process: early intense absorption of RS was followed by the later and less intense absorption of VFA, which, thus, helped to bridge the energy gap. The exact physiological significance of this phenomenon is worth investigating.

\section{ACKNOWLEDGMENTS}

P Butler is acknowledged for translating the French manuscript into English, and $\mathrm{J}$ Galle for the drawings.

\section{REFERENCES}

Argenzio RA, Southworth M (1975) Sites of organic acid production and absorption in gastrointestinal tract of the pig. Am J Physiol 228, 454-460

Bach Knudsen E, Jensen BB, Hansen I (1993) Digestion of polysaccharides and other major components in the small and large intestine of pigs fed on diets consisting in oat fractions rich in $\beta$-D-glucan. $B r J$ Nutr 70 , $537-556$

Barcroft JR, McAnally RA, Phillipson AT (1944) Absorption of volatile acids from the alimentary tract of the sheep and other animals. J Exp Biol 20, 120-129

Bergmeyer HU, Gruber W, Gutbann I (1974) D-Sorbitol. In: Methods of Enzymatic Analysis (HU Bergmeyer, ed), Vol 3, Academic Press, New York, 1323-1326

Charlet-Lery G (1964) Utilization of the energy of lactic acid by the growing pigs. Comparison with starch. Proc 3rd Symp on Energy Metabolism, Troon, UK, publ 11, EAAP, Acad Press Inc, London, 279-284

Clemens ET, Stevens CE, Southworth M (1975) Sites of organic acid production and pattern of digesta movement in the gastrointestinal tract of swine. J Nutr 105, 759-768

Cranwell PD, Noakes DE, Hill KJ (1976) Gastric secretion and fermentation in the suckling pig. Br J Nutr 36 , 71-86

Etienne M (1969) Premiers résultats concernant les quantités d'acides gras volatils et d'acide lactique présentes dans le tube digestif du porc. Journ Rech Porcine en France, Paris, INRA-ITP, 131-136

Farrell DJ, Johnson KA (1972) Utilization of cellulose by pigs and its effects on caecal function. Anim Prod 14, 209-217

Friend DW, Nicholson JWG, Cunningham HM (1964) Volatile fatty acid and lactic acid content of pig blood. Can J Anim Sci 44, 303-308

Gargallo J, Zimmerman DR (1980) Effects of dietary cellulose and neomycin on function of cecum of pigs. $J$ Anim Sci 51, 121-126

Gawehn D, Bergmeyer HU (1974) D-(-)-Lactate. In: Methods of Enzymatic Analysis (HU Bergmeyer, ed), Academic Press, New York, vol 3, 1492-1495

Giesecke D, Stangassinger M (1980) Lactic acid metabolism. In: Digestive Physiology and Metabolism 
in Ruminants (Y Ruckebush, $\mathrm{P}$ Thivend, eds), MTP Press Ltd, Lancaster, UK, 523-539

Giusi A (1986) Influence du niveau alimentaire et de la composition du régime sur la production intestinale et l'absorption des acides gras volatils chez le porc éveillé. Doctoral thesis, Paris-VI, $120 \mathrm{p}$

Giusi-Perier A, Fiszlewicz M, Rérat A (1989) Influence of diet composition on intestinal volatile fatty acids and nutrient absorption in anaesthetized pigs. J Anim Sci 67, 386-402

Hecker JF, Grovum WL (1975) Rates of passage of digesta and water absorption along the large intestines of sheep, cows and pigs. Austr J Biol SCi $28,161-167$

Heller MD, Kern F (1968) Absorption of lactic acid from an isolated intestinal segment in the intact rat. Proc Soc Exp Biol Med 127, 1103-1106

Hill JB, Kessier G (1961) An automated determination of glucose utilizing a glucose oxidase-peroxidase system. J Lab Clin Med 57, 970-980

Hodgman C (1959) Handbook of Chemistry. 40th edition, Chemical Rubber Publishing, Cleveland, $\mathrm{OH}$

Hoffman SW (1937) A rapid photoelectric method for the determination of glucose in blood and urine. $J$ Biol Chem 120, 511-555

Imoto S, Namioka S (1978a) VFA production in the pig large intestine. J Anim Sci 47, 467-478

Imoto S, Namioka S (1978b) VFA metabolism in the pig J Anim Sci 47, 479-487

Kass ML, Van Soest PJ, Pond WG (1980) Utilization of dietary fiber from alfalfa by growing pigs. II. Volatile fatty acid concentrations in and disappearance from the gastrointestinal tract. J Anim Sci 50, 192-197

Kennelly JJ, Aherne FX, Sauer WC (1981) Volatile fatty acid production in the hindgut of swine. Can J Anim 61,349

Koch G, Ledinek M, Giesecke D (1972) The participation of micro-organisms in digestive metabolism of pigs. 1. Studies on slaughter pigs. Z Tierphysiol Tieremähr Futtermittelk 30, 222-231

Ledinek M (1970) Role of micro-organisms in digestion of raw and cooked potatoes by pigs. Diss Tierärztl Fak Ludwig-Maximilians, Univ Munich, Germany, $101 \mathrm{p}$

Ly J (1974) Caecal function in the pig: VFA content and utilization by the caecal wall. Cuban J Agric Sci 8 , 247-254

McClymont GL (1951) Identification of the volatile fatty acid in the peripheral blood and rumen of cattle and the blood of other species. Austr J Agric Res 2, 92103

Minaire Y, Foucherand F, Studievic C (1965) Adaptation du dosage de l'acide lactique par voie enzymatique à l'autoanalyzer. IV. Technicon International Symposium, Paris, Compagnie Technicon, Domont, France
Palmer DW, Peters R (1966) Simple automatic determination of amino groups in serum-plasma using trinitrobenzenesulfonate. In: Automation in Analytical Chemistry (LT Skeggs, Jr, ed), Mediad, New York, 324-327

Rérat A (1978) Digestion and absorption of carbohydrates and nitrogenous matters in the hindgut of the omnivorous non-ruminant animal. J Anim Sci 46 , 1808-1837

Rérat A (1981a) Contribution du gros intestin à la digestion des glucides et des matières azotées chez le monogastrique omnivore. Reprod Nutr Dev 21, 815 849

Rérat A (1981b) Chronologie et bilans de l'absorption des sucres réducteurs et de l'azote $\alpha$-aminé chez le porc selon la nature des aliments. Bull Acad Nat Med 165, 1131-1137

Rérat A (1982) Absorption des sucres et des acides aminés chez le porc. In: Digestive Physiology in the Pig (JP Laplace, T Corring , A Rérat, eds), Colloques de I'INRA No 12, INRA Pub Ed, 63-87

Rérat A (1988) Experimental results on gut physiology and absorption as related to amino acid nutrition and metabolism. Roche Research Prize for Animal Nutrition, Roche, Basel, Switzerland, $49 \mathrm{p}$

Rérat A, Vaissade $P$ (1993) Relations entre la prise alimentaire et la consommation d'oxygène des organes drainés par la veine porte chez le porc éveillé. Reprod Nutr Dev 33, 235-251

Rérat A, Corring T, Laplace JP (1978) Quelques aspects des recherches en physiologie digestive chez le porc : applications possibles. Journ Rech Porcine en France, INRA-ITP, Paris, 95-119

Rérat A, Vaugelade P, Villiers P (1980) A new method for measuring the absorption of nutrients in the pig: critical examination. In: Current Concepts of Digestion and Absorption in Pigs (AG Low, IG Partridge, eds) Tech Bull 3, NIRD, Reading, UK, 177-214

Rérat A, Vaissade P, Vaugelade P (1984) Absorption kinetics of some carbohydrates in conscious pigs. 2. Quantitative aspects. Br J Nutr 51, 517-529

Rérat $A$, Fiszlewicz $M$, Herpin $P$, Vaugelade $P$, Durand $M$ (1985) Mesure de l'apparition dans la veine porte des acides gras volatils formés au cours de la digestion chez le porc éveillé. CR Acad Sci, Paris, 300, Série III, 467-470

Rérat A, Fiszlewicz M, Giusi A, Vaugelade P (1987) Influence of meal frequency on post-prandial variations in the production and absorption of volatile fatty acids in the digestive tract of conscious pigs. J Anim Sci 64, 448-456

Rérat A, Vaissade $P$, Vaugelade $P$ (1990) Kinetics and balance of glucose and galactose appearance in the portal blood after intake of lactose or hydrolysed lactose in conscious pigs. Ann Nutr Metab 34 119-132 
Rérat A, Vaissade P, Vaugelade $P$ (1991) Comparative digestion of maltitol or maltose in unanesthetized pigs. J Nutr 121, 737-744

Rérat A, Simoes-Nunes C, Mendy F, Vaissade $P$, Vaugelade $P$ (1992) Splanchnic fluxes of aminoacids after duodenal infusion of carbohydrate solutions containing free amino-acids or oligopeptides in the nonanaesthetized pig. $\mathrm{Br} J$ Nutr $68,111-138$

Rérat A, Giusi-Perier A, Vaissade P (1993) Absorption balances and kinetics of nutrients and bacterial metabolites in conscious pigs after intake of maltose- or maltitol-rich diets. J Anim Sci 71, 2473-2488

Schiemann T, Nehring K, Hoffmann L, Jentsch W, Chudy A (1971) Energetische Futterbewertung und Energienormen. VEB Deuscher Landwirtschaftsverlag, Berlin, Germany
Stanogias G, Pearce GR (1985) The digestion of fibre in pigs. 2. Volatile fatty acid concentrations in large intestine digesta. Br J Nutr 53, 531-548

Topping DL, IIIman RJ, Taylor MN, McIntosch GH (1985) Effects of wheat bran and porridge oats on hepatic portal venous volatile fatty acids in the pig. Ann Nutr Metab 29, 325-331

Windmueller HG, Spaeth AE (1978) Identification of ketone bodies and glutamine as the major respiratory fuels in vivo for post-absorptive rat small intestine. J Biol Chem 253, 69-76

Yen JT, Nienaber JA, Hill DA, Pond WG (1991) Potential contribution of absorbed volatile fatty acids to whole-animal energy requirement in conscious swine. J Anim Sci 69, 2001-2012 